\title{
Moscow scraps Indian rocket deal under US pressure
}

Washington \& New Delhi. A Russian decision, under US pressure, not to sell advanced rocket technology to India has provoked resentment in New Delhi, dismay in Moscow and contentment in Washington.

But the development has smoothed the way for collaboration between Russia and the United States on various space projects, although it is still uncertain what shape this cooperation will take.

Earlier this month, the United States and Russia settled the long-standing dispute over Russia's 1991 contract to sell to India cryogenic rocket engines and the technology to

\section{IMAGE UNAVAILABLE FOR COPYRIGHT REASONS}

\section{The Russian Proton rocket could launch parts of the US space station.}

build them. The United States argued that the sale violated international non-proliferation agreements because the engine technology could be used for missile launchers. India and Russia have dismissed the charge as absurd.

Nevertheless, Russia has now agreed to sell only assembled engines to India and not the technology. More important from the US standpoint, Russia has agreed to abide by the terms of the Missile Technology Control Regime (MTCR). The United States had feared that cash-hungry Russia might sell military technology indiscriminately: it was reported to have sold submarines to Iran and ingredients of rocket fuel to Libya.

The United States told the Russians that, unless they settled, it would withdraw an offer to allow them limited entry to the commercial satellite launch market. It also threatened to ban all US dealings with $\mathrm{KB}$ Salyut, the Russian partner in the Indian rocket deal. Because KB Salyut also designs space vehicle hardware, the ban would have blocked Russian participation in the US space station and shuttle programmes.

The day after Russia agreed to scrap its deal with India, the US unblocked the satellite launch agreement (see Nature 363, 661; 1993). The Russian Prime Minister, Viktor Chernomydrin, is expected to sign this agree- ment when he visits the United States in August or September. On the same day, the Russian space agency and the National Aeronautics and Space Administration agreed to identify areas for cooperation. They will do so in time for Chernomydrin's visit.

During the often heated negotiations on the Indian rocket agreement (whose value may be as much as $\$ 400$ million), Russian officials repeatedly demanded compensation for the revenue Russia would lose. Neither side admits to a quid pro quo, but the United States will now probably buy Russian space hardware.

Russia also hopes that the United States will put the station in an orbit that Russian rockets can launch to. They could then help build and/or eventually service it. Congressman George Brown (Democrat, California), chairman of the Science, Space and Technology Committee House of Representatives and an influential supporter of the space station, hinted last week that the United States could quickly agree to this.

But Roald Sagdeev, a former Soviet space official who heads the Washington-based East-West Science and Technology Center, warns that the US Congress or the international partners in the space station could still block major Russian involvement. His "greatest concern" is that US aerospace companies might see Russia as a competitor for "their piece of pie".

In Moscow, some see Russia's capitulation as betrayal. Nikolai Semyonov, an official of Glavkosmos, the commercial arm of the Russian space programme, was reported as saying that "they [the United States] are trying to tie a dead cat around our necks": one fear is that the United States is trying to stifle the Russian space industry to protect its markets.

In India, scientists at the Indian Space Research Organization (ISRO) understandably feel cheated. Russia had assured them, as recently as this spring, that the deal would go through. The rocket engines are critical to ISRO's plan to build a geostationary launch vehicle (GSLV). Russia will renegotiate the contract in New Delhi next month, but ISRO's chairman, Professor U. R. Rao, says that, without the technology, "the contract is as good as scrapped; there will be nothing further to negotiate."

Even so, Russia is said to have already delivered more than half the technical drawings for the rocket, and some in India believe it could develop the technology itself. "We have the capacity, but it will take time and much money," says R. Narasimha, director of India's National Aeronautical Laboratory in Bangalore.

Tony Reichhardt \& K.S. Jayaraman
French state sells shares in Elf Aquitaine and Rhône-Poulenc

Paris. France's newly elected Conservative government has kept its pledge to speed up the sale of state holdings. First on the block are the chemicals and pharmaceuticals giant Rhône-Poulenc and the oil-to-chemicals company Elf Aquitaine - scheduled to be sold in September. Together they spent over FF10.6 billion on research and development last year

Officially, both companies say the sale of state-owned shares will have little effect on either business or R\&D strategies. But both have most of their research based in France, yet are pushing to internationalize their market influence; it would be surprising if privatization did not affect their R\&D capacity in France.

Rhône-Poulenc - which was partly privatized earlier this year leaving the state with 43 per cent of the shares - invested FF5.96 billion in R\&D last year. It has 19 major research centres worldwide, nine in France. But only four of its 11 life science centres are in France. "There will not be a step change but the globalization of $R \& D$, which started in 1986 when the company hit the international acquisitions trail, will continue to evolve," says one London-based chemicals analyst.

Rhône-Poulenc's R\&D strategy involves tight links with French public research institutions. More than 300 researchers take part in the FF1.6 billion BioAvenir programme. BioAvenir is designed to develop quickly fundamental biology research of commercial promise. The company's privileged access to innovations from some of the world's most productive laboratories will not harm the value of the government's holding when it sells.

When BioAvenir was launched, critics alleged it was a guise for state aid. The company has since invited others to invest, but none has yet done so. Rhône-Poulenc has hinted it might create a similar programme to develop chemical R\&D. But the French government may be less willing to invest in a company in which it has no stake.

Elf-Aquitaine employs nearly 6,000 researchers from a budget of FF4.62 billion in 1992. It spends most — almost half - on health-care research, followed by chemicals ( 29 per cent) and hydrocarbons (18 per cent).

As a concession to President François Mitterrand, the French government will probably keep a golden share in the strategic group; it currently holds a half stake. Privatization, says a company spokesman, would probably not affect its business or research strategies. But the company supports fundamental research and has 520 research contracts with public research organizations.

Mike Ward 